\title{
A NEW METHOD FOR TREATING THE BALLAST WATER BY HEATING
}

\author{
ACOMI, N[icoleta]; POPESCU, C[orina]; VARSAMI, A[nastasia] E[lena]; \\ CHIRCOR, M[ihael] \& GROSAN, V[oicu] - N[icolae]
}

\begin{abstract}
In this paper we intend to discuss the prevention of marine species' transfer from a different maritime area to another. The main instrument used in such situations is the International Convention for Control and Management of Ship's Ballast Water and Sediments - BWM, 2004, which introduces the quality standards that the ballast water has to comply with after it has been treated by using different methods. Further on, we are presenting a solution for treating the ballast water by heating it, after modifying the ballast installation onboard and using the abstracted thermal energy from the main engine. We have managed this by making two major modifications of the onboard cooling circuits: one is represented by the modification of the seawater system existing onboard and the second modification is represented by the usage of the abstracted thermal energy from the main engine by fixing a heat exchanger on the freshwater cooling system.

Keywords: ship, ballast water, method, heat exchanger
\end{abstract}

\section{INTRODUCTION}

The ballast water carried onboard ships, which is used due to stability reasons, contains live organisms. These organisms can be molluscs, crabs, kelp, phytoplankton, zooplankton, viruses, bacteria, and different types of parasites, pathogenic organisms, shells and different biological species' larva. During the operation of de-ballasting the ship, these organisms get into the destination aquatic environment.

The methods of using engine heat are based on the medium heat treatment strategies and can be obtained depending on time voyage limitations, open ocean depth, and seawater temperature.

The journey time and seawater environment temperature are the most important constraints for ballast water heat treatment.

As actual available diesel engine waste heat is determined from engine data supplied by manufacturer, some researchers tried to calculate the heat dissipation for different engines.

For example (Radan, D., Lovric, J. 2002) adapted the conventional seawater cooling system to achieve maximum temperature. Modification of conventional seawater cooling system proposed by them served to achieve maximum seawater cooling outlet temperature. By connecting scavenge air cooler outlet to jacket water cooler inlet, the seawater cooling system outlet temperature could be raised to $50^{\circ} \mathrm{C}$ or more. Additional heat exchanger should be two stages. $63.4 \%$ cooling seawater pump flow capacity with approx. maximum temperature of $40^{\circ} \mathrm{C}$ will pass through the first stage of heat exchanger while the other $36.6 \%$ with approx. temperature of $50^{\circ} \mathrm{C}$ will pass through the second stage.

All explored options are based on biological heat treatment strategies which are shown in table 1.

It is very hard to determine the duration of exposure at temperature sufficient for complete organism inactivation because of the huge amount of marine species contained in ballast water. Therefore, only the most resistant organisms have been tested (Hallegraef, G.M, el al. 1997), (Mountfort, D. O. et al 1999).

\begin{tabular}{|l|l|l|}
\hline Exposure & Duration & Temperature \\
\hline Short & $\leq 10$ minutes & $\geq 46^{\circ} \mathrm{C}$ \\
\hline Medium & 10 min. to 16 hours & 36 to $45^{\circ} \mathrm{C}$ \\
\hline Long & $\geq 16$ hours & $\leq 36^{\circ} \mathrm{C}$ \\
\hline
\end{tabular}

Tab. 1. Near complete kill of the most resistant organism

Heating the ballast water at temperatures between $35^{\circ} \mathrm{C}$ and $45^{\circ} \mathrm{C}$, and maintain these temperatures for a long enough period is efficient for killing the organisms and less efficient for micro-organisms. The method that we are going to describe in this paper is called treating the ballast water by heating.

\begin{tabular}{|l|c|l|l|}
\hline Species & Temp. & Time & Source \\
\hline & ${ }^{\circ} \mathrm{C}$ & h.m.s. & \\
\hline G. catenatum & $35-37.5$ & $1-2 \mathrm{~h}$ & Hallegraeff et al. (1997) \\
\hline $\begin{array}{l}\text { G. catenatum } \\
\text { Alexandrium } \\
\text { Sp. }\end{array}$ & $40-45$ & $30-90 \mathrm{~s}$ & $\begin{array}{l}\text { Bolch and Hallegraeff } \\
(1993)\end{array}$ \\
\hline A. cattenella & 38 & $3 \mathrm{~m}$ & Montani et al (1995) \\
\hline
\end{tabular}

Tab. 2. Organisms and micro-organisms that are subject of the heating treating

\section{THE PROPOSED METHOD}

After the studies made in the laboratory, by heating the ballast water at different temperatures (between $38^{\circ} \mathrm{C}$ and $45^{\circ} \mathrm{C}$ ), it has been noticed that the organisms and micro-organisms died after certain periods of time (1-5 days) of maintain constant the water temperature (Rigby et al., 1999).

The advantage of this method is represented by the fact that it is not necessary any treating equipment acquisition, because the method is using the heat that is lost when cooling the main engine, and it is enough only to modify this installation; the treating process is efficient because it is done in the whole ballast tank and 
this way we can obtain an inactivation of the sediments on the bottom of the ballast tank.

The disadvantage of this particular method is represented by the fact that it is difficult to heat and to maintain this particular heat at a certain temperature for the whole quantity of the ballast water onboard the ship; because of this, treating by heating is done for a single tank and afterwards there is a transfer of the treated water in different tanks.

Applying this method does not present risks because the additional equipment that are going to be installed for heating the ballast water (heat exchangers) are ordinary equipment onboard the ship.

The laboratory results showed different levels of efficiency depending on the target organisms and on the maintained temperature and the exposure period.

Because the treating is done in a single ballast tank and afterwards there is a ballast water transfer from one tank to another, the equipment is recommended to be used on cargo or container ships.

In the case of these types of ships, as the ballast water operations' log book shows, the loaded quantities are small and the operations are performed often, but in the case of tankers, the whole cargo quantity is discharged in a single port, and the ship is going to sail with full loaded ballast water tanks to the next loading port. There is no contaminated residue as a result of the system of treating the ballast water by heating and the resulted waters can fi discharged with no harmful impact on the environment. The ballast water heating system has the following components heat exchanger and pumps for taking over the ballast water from the tank and for re-cycling it through the heat exchanger.

The maintenance of this equipment is done by the personnel onboard the ship and there is no need of special qualification courses for the crew.

According to the laboratory experiments, the disinfection rate depends on the applied temperature and the time period that the temperature is kept for.

\section{DETAILED DESCRIPTION OF THE PROPOSED METHOD}

\subsection{The Main Seawater System to the Coolers - Initial Diagram.}

The seawater is aspirated and circulated by two electric pumps from the suction sea chest through the seawater filters. The debit of these pumps is distributed to five coolers that are in parallel connection:

- No. 1 and 2 coolers for freshwater

- Condenser

- Freshwater coolers from No. 1 and 2 Diesel Generators

\section{- Air Condition}

During the loading/discharging operations it is necessary a higher debit of the cooling water. For this, the system is equipped with an auxiliary pump.

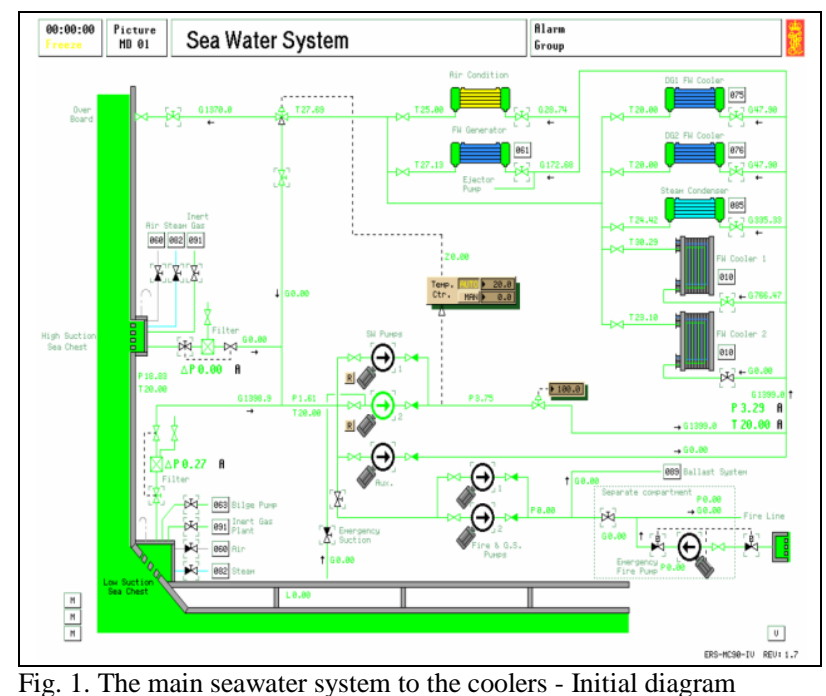

The seawater is aspired by Low Suction Sea Chest when the ship is sailing or by High Suction Sea Chest when the ship is loaded with cargo.

In order to avoid low temperatures of the seawater when it is entering the coolers, a recycling thermoregulatory valve is being used in order to circulate the water through the discharge overboard pressure line to the suction sea chest.

The recycling valve is controlled by a standard PID controller.

The recycling line is smaller and has higher flow resistance than the discharge overboard pressure line. This way, the total debit of the seawater will be reduced for the recycling line.

There are several modifications brought to the cooling system of the main engine.

First step towards the ballast water heating is to use the seawater flow (variable when the seawater temperature is below $15^{\circ} \mathrm{C}$ ) from the discharge overboard lines, heated with no extra costs up to $27^{\circ} \mathrm{C}$.

\subsection{The Main Seawater System - Intermediary Diagram.}

As it can be seen in the diagram, the seawater which is circulated to the ballast tanks is aspired through the same suction sea chests. By installing additional suction lines, the seawater will get into the ballast tanks with the same temperature and debit as the seawater in the discharge overboard pressure line.

Modification 1, proposed for the ballast installation, the seawater system consists of fixing a pump on the overboard circuit and directing it to the ballast tank.

The seawater debit and temperature in the discharge overboard circuit that we are going to use for calculating the pump's and lines' dimensioning are taken from the Kongsberg Maritime, MAN B\&W5L90MC main engine simulation programme:

- Total debit from the overboard line $=1370 \mathrm{~m}^{3} / \mathrm{h}$

- Overtaken and directed debit towards the ballast tank $=700 \mathrm{~m}^{3} / \mathrm{h}$ 
- Temperature $=25^{\circ} \mathrm{C}$

- Seawater density $=1.025 \mathrm{~kg} / \mathrm{dm}^{3}$

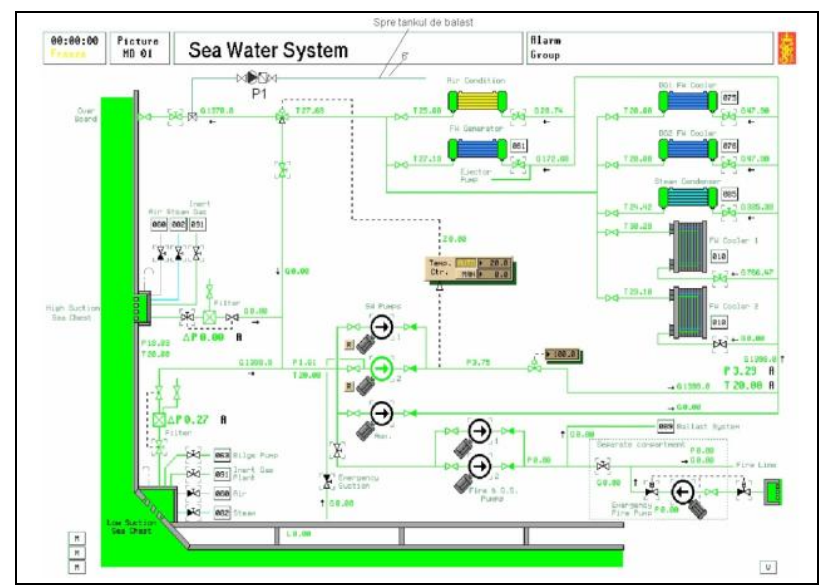

Fig. 2. Modified system of the seawater suction from the overboard line and introducing it in the ballast tank

\subsection{The Fresh Water Cooling System - Initial Diagram.}

The fresh water cooling system is divided in two subsystems:

- The low temperature cooling system

- The high temperature cooling system

Modification 2 appears due to the fact that given that the resulted temperature of approximately $23^{\circ} \mathrm{C}$ is not enough for killing micro-organisms we suggested increasing temperature in the ballast tank using a heat exchanger.

Part of the fresh water debit in the cooling circuit of high temperature $\left(85^{\circ} \mathrm{C}\right)$ of the main engine will be transferred through a heat exchanger in order to increase water temperature in the tank up to $45^{\circ} \mathrm{C}$.

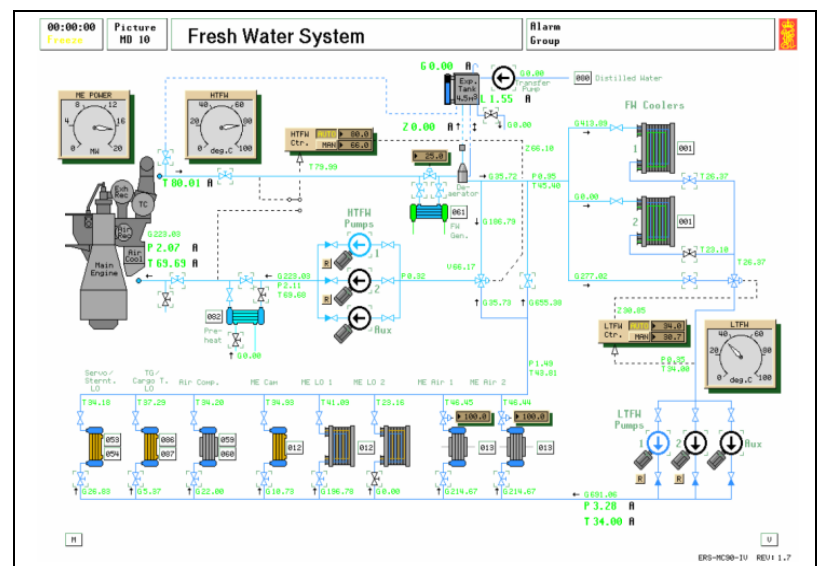

Fig. 3. The freshwater cooling system - Initial diagram

\subsection{The Fresh Water Cooling System - Final Diagram.}

The following characteristics have been used in order to define the system:

- Total debit in the cooling system of High temperature $=225 \mathrm{~m}^{3} / \mathrm{h}$
- Overtaken and directed debit towards the heat exchanger $=45 \mathrm{~m}^{3} / \mathrm{h}$

- Temperature $=80^{\circ} \mathrm{C}$

- Fresh water density $=1.000 \mathrm{~kg} / \mathrm{dm}^{3}$

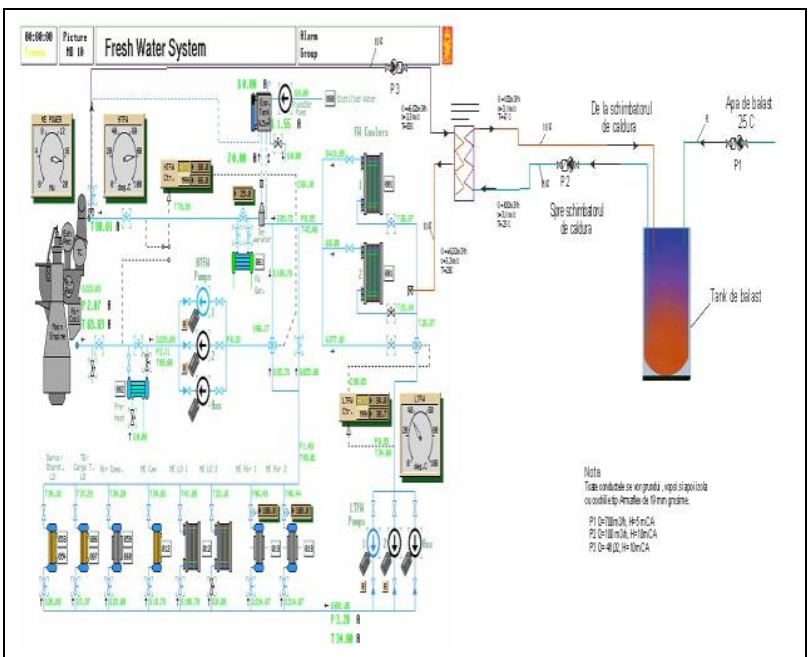

Fig. 4. Modified system for overtaking the water from the high temperature circuit, transferring it through the heat exchanger and introducing fresh water into the fresh water system

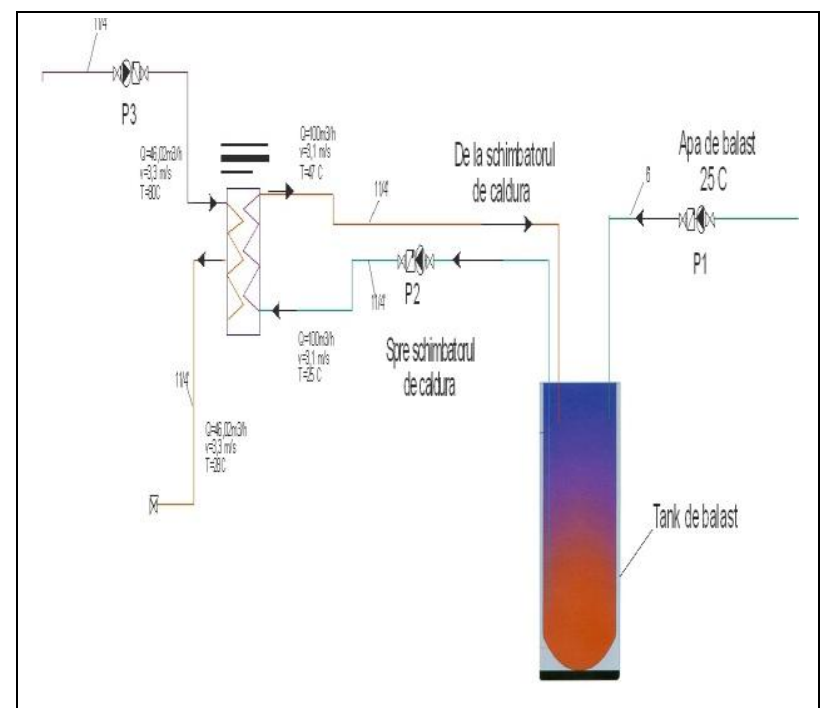

Fig. 5. Modified system for overtaking the water from the high temperature system and introducing it in the heat exchanger

In order to achieve the dimensioning of the heat exchanger it has been used the programme from the Danfoss company and it has been taken into account the entrance flows of the two agents but also the temperature gap between entrance and exit.

We have chosen the following characteristics in order to establish the dimensioning of the board-type exchanger. 


\begin{tabular}{|c|c|c|c|}
\hline \multicolumn{4}{|c|}{ Heat exchanger characteristics } \\
\hline $\begin{array}{l}\text { Heat exchanger } \\
\text { type }\end{array}$ & & \multicolumn{2}{|c|}{ XB $70-1200$} \\
\hline & & \multicolumn{2}{|c|}{ HEATING } \\
\hline Danfoss Code & & \multicolumn{2}{|c|}{ 004B2499 } \\
\hline PED - Category & & \multicolumn{2}{|c|}{ II } \\
\hline Capacity & {$[\mathrm{kW}]$} & \multicolumn{2}{|c|}{2768} \\
\hline & & Hot Side & Cold Side \\
\hline Flow rate & {$[\mathrm{m} 3 / \mathrm{h}]$} & 46.02 & 100.00 \\
\hline Temperature in & {$\left[{ }^{\circ} \mathrm{C}\right]$} & 80 & 23 \\
\hline Temperature out & {$\left[{ }^{\circ} \mathrm{C}\right]$} & 28 & 47 \\
\hline $\begin{array}{l}\text { Real pr. flow/ ret. } \\
\text { temp. }\end{array}$ & {$\left[\mathrm{m}^{3} / \mathrm{h} /{ }^{\circ} \mathrm{C}\right]$} & 46.020 & 27.5 \\
\hline LMTD & {$\left[{ }^{\circ} \mathrm{C}\right]$} & 14.8 & 14.4 \\
\hline Pressure drop & {$[\mathrm{kPa}]$} & 7 & 16 \\
\hline Velocity & $\mathrm{m} / \mathrm{s}$ & 3.3 & 3.1 \\
\hline \multicolumn{4}{|l|}{$\begin{array}{l}\text { Physical } \\
\text { Dimensions }\end{array}$} \\
\hline $\begin{array}{l}\text { Number } \\
\text { element }\end{array}$ & & 99 & 100 \\
\hline Water volume & [1] & 54.45 & 70.00 \\
\hline Over-surfacing & {$[\%]$} & \multicolumn{2}{|c|}{10.00} \\
\hline All heat surface & {$\left[\mathrm{m}^{2}\right]$} & \multicolumn{2}{|c|}{47.32} \\
\hline Total weight & {$[\mathrm{kg}]$} & \multicolumn{2}{|c|}{340} \\
\hline \multicolumn{4}{|l|}{$\begin{array}{l}\text { Physical } \\
\text { Properties }\end{array}$} \\
\hline $\begin{array}{l}\text { Hot Side flow } \\
\text { media }\end{array}$ & & Water & \\
\hline $\begin{array}{l}\text { Cold Side flow } \\
\text { media }\end{array}$ & & Water & \\
\hline Heat capacity & {$[\mathrm{kJ} / \mathrm{kgK}]$} & 4.185 & 4.176 \\
\hline Density & {$\left[\mathrm{kg} / \mathrm{m}^{3}\right]$} & 986.2 & 994.1 \\
\hline Viscosity & {$\left[\mathrm{mNs} / \mathrm{m}^{2}\right]$} & 0.502 & 0.702 \\
\hline $\begin{array}{l}\text { Thermal } \\
\text { conductivity }\end{array}$ & {$[\mathrm{W} / \mathrm{mK}]$} & 0.651 & 0.624 \\
\hline
\end{tabular}

Tab. 3. Main characteristics for dimensioning the board-type exchanger

By introducing P2 pump we take over the seawater from the ballast tank and circulate it through the above heat exchanger in order to take it in contact with the warm agent resulted from sweet water $\mathrm{Q}_{\text {inHE-FW }}=46$ $\mathrm{m} 3 / \mathrm{h} ; \mathrm{T}_{\text {inHE-FW }}=80^{\circ} \mathrm{C}$. In order to select the pump it was used WILO-Select programme, taking into account the hydraulic data necessary for our purpose.

$$
\mathrm{Q}_{\text {inHE-Sw Debit }}=100 \mathrm{~m}^{3} / \mathrm{h}, \mathrm{H}=10 \mathrm{mCA}
$$

Input temperature $\mathrm{T}_{\text {inHE-SW }}>25^{\circ} \mathrm{C}$, as the temperature increases in the ballast tank.

Sea water density $\mathrm{Ro}_{\mathrm{SW}}=1,025 \mathrm{~kg} / \mathrm{dm}^{3}$

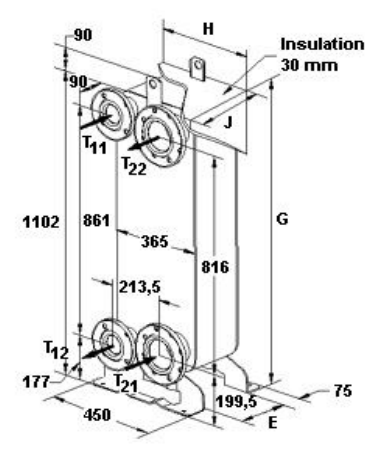

Fig. 6. External dimensions in [mm] of the heat exchanger and the ballast tank with the correspondent entrances and exits

\section{CONCLUSION}

Some modification must be brought to the cooling installation in order to take the ballast water into contact with the heat from the main engine. The treatment using this method is limited by the heat quantity provided by the engine, so that the water quantity with must be treated will depend upon the available quantity of heat from the main engine.

We intend to calculate heat losses for a ballast tank while the ship is navigating at different temperatures and also the isolation possibility for it.

\section{REFERENCES}

[1] Bolch, C.J.; Blackburn, S.I.; Hallegraeff, G.M.\& Vaillancourt, R.E. (1998). Molecular genetic variation among different global populations of the toxic dlnoflagellate Gyninodinjum catenatum revealed by RAPD-PCR. Proc 8th Int Conf Harmful Algae, Vigo, p 283-286

[2] Bolch, C.J. \& Hallegraeff, G.M. (1990). Dinoflagellate cysts inrecent marine sediments from Tasmania, Australia. BotMar 33:173-192

[3] Bolch, C.J. \&Hallegraeff, G.M. (1993). Chemical and physicaloptions to $\mathrm{k} \sim 11$ toxic dinoflagellate cysts in ships' ballast water. J Mar Environ Engineering 1:23-29

[4] Gustaaf M. Hallegraeff.(1998).Transport of toxic dinoflagellates via ships' ballast water: bioeconomic risk assessment and efficacy of possible ballast water management strategies School of Plant Science, University of Tasmania, GPO Box 252-55, Hobart, Tasmania 7001, Australia, Marine Ecology Progress Series, Vol 168: 297-309

[5] Hallegraeff, G.M.; Valentine, J.P.; Marshall, J.A. \& Bolch, C.J. (1997). Temperature tolerances of toxic dinoflagellate cysts: Application to the treatment of ship's ballast water, Aquatic Ecology, 32

[6] MAN B\&W Diesel A/S. MC Programme Engine Selection Guide, Copenhagen, Denmark, Feb., 1992

[7] Mountfort, D.O.; Dodgshun, T.; Gibbs, W. \& McCallin B Towards a feasible heat treatment system for ship's ballast water, Proceedings of a workshop, Hillman, S. P.: EcoPorts MonographSeries No.19, Brisbane, Australia, May, 1999

[8] New Sulzer Diesel Ltd. Engine Selection and Project Manual: Sulzer RTA52U, RTA62U, RTA72U, Diesel Engines, Winterthur, Switzerland, Nov., 1994 